Revista Eletrônica Geografar, Curitiba, v. 2, Resumos do VI Seminário Interno de Pós-Graduação em Geografia, p. 29-29. Junho/2007

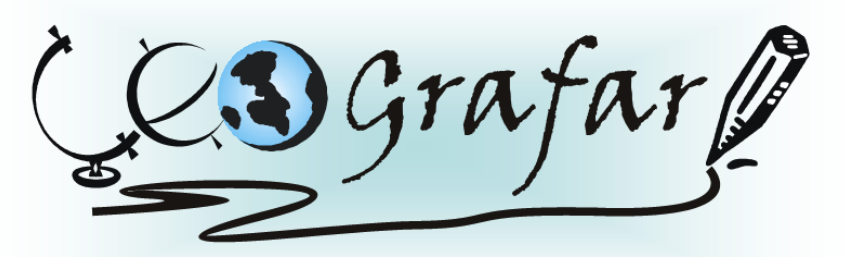

Revista Eletrônica do Programa de Pós-Graduação em Geografia - UFPR

\title{
ESTRUTURAÇÕES IDENTITÁRIAS NO ESPAÇO DE REPRESENTAÇÃO DO FUTEBOL
}

\section{FERNANDO ROSSETO GALLEGO CAMPOS ${ }^{1}$}

O presente trabalho tem como objetivo discutir as estruturações identitárias produzidas no interior do espaço de representação do futebol. Ele foi elaborado a partir das formulações de Lefébvre (1991), Soja (1996) e Gil Filho (2003). Ele possibilita apreender o futebol não apenas como esporte, mas também como manifestação sócio-espacial e cultural, pois através da criação e circulação de representações socais (MOSCOVICI, 2004), o futebol está presente de forma significativa no cotidiano dos brasileiros, construindo uma instância da espacialidade própria. O espaço de representação do futebol é composto por diversos elementos, que se dividem em categorias centrais (fato futebolístico, prática social do futebol e poder), categorias de mediação (símbolo, mito moderno, discurso, identidade futebolística) e reinos (política institucional, ethos futebolístico e paixão/afetividade). A estruturação identitária - referida como identidade futebolística - configura-se como elemento fundamental na construção desta instância da espacialidade, estando intimamente ligada aos demais elementos. É extremamente complexa, pois assume diversas facetas, tais como a identidade clubística (ligada à paixão clubística) e a questão da construção de uma suposta identidade nacional. As discussões acerca das estruturações identitárias têm como ponto de partida as formulações de Hall (2005) sobre a identidade na pós-modernidade, bem como a socialidade, de Maffesoli (2005 e 2006). Este defende a idéia de que a pósmodernidade pode ser caracterizada pelo retorno exacerbado do arcaísmo - acompanhado do tribalismo - e pela emergência da dimensão comunitária em contraponto ao indivíduo um conceito saturado. O paradigma moderno do social - individualista, racional e baseado no poder das organizações econômico-políticas - é substituído pelo paradigma da socialidade, baseado em um ethos comunitário, na massificação e na constituição de tribos afetuais. Assim, a identidade - fixa e estável - perde seu sentido. A lógica da socialidade é afetiva e a estruturação identitária baseia-se em questões simbólicas.

Palavras-chave: estruturação identitária; identidade futebolística; espaço de representação do futebol.

'Doutorando em Geografia - UFPR - email:fgallego@gmail.com

Orientador: SYLVIO FAUSTO GIL FILHO Co-orientador: WOLF DIETRICH SAHR 